\title{
Ungern och judarna. Ett schizofreniskt svar på en ovanlig assimilation
}

\author{
Den ungerska judendomens ursprung och ideologiska splittring
}

\section{Av Attila Lajos, doktorand i historia}

\author{
Länk till presentation av Attila Lajos
}

Judarna i Ungern har en gammal historia och magyarernas (ungrarnas) kontakter med judendomen går kanske tillbaka till det första årtusendets mitt, när magyarerna levde under kazarernas överhöghet någonstans norr om Kaspiska och Svarta havet i den legendariska ungerska urhemmet, Levedia.[1] Spår av judiskt liv kunde även hittas i romarnas Aquincum, bredvid vilkas ruiner Budapest byggdes. Sedan fanns de med redan i Sankt Stefans kungarike strax efter år 1000. De fanns även med när den ungerska huvudstaden Buda föll 1541 under turkarna, och de var förmodligen den enda befolkningsgruppen som trivdes under den ottomanska ockupationen. Men sedan minskade deras antal starkt och den överväldigande majoriteten av den moderna ungerska judendomen hade ett trefaldigt men senare ursprung beroende på varifrån de hade invandrat till Ungern.[2] Den äldsta grupperingen som fortfarande var medveten om sitt ursprung var judarna som invandrade från Österrike under andra delen av 1600-talet efter det att kejsaren Leopold I hade förvisad dem från Wien. De bosatte sig i västra Ungern och blev huvudsakligen handelsmän och småproducenter. De fortsatte tala främst tyska ända fram till 1800-talets andra del och representerade en konservativ barockkultur.

Den andra gruppen utgjordes av de judar som blev borttvingade från de tjeckiska och Moraviska delarna av riket, särskild efter det att Maria Teresa hade begränsat antalet judiska familjer som fick bo i Tjeckien till max. 10 000. Dessa judar var rikare och bättre utbildade än sina föregångare och kom så småningom att dominera det judiska livet i västra Ungern och Budapest. I motsats till den först nämnda grupperingen bar de med sig upplysningens idéer och var reformvänliga. De flesta blev egalitarismens och assimilationens anhängare, och omvandlade sig till "ungrare av judisk tro" utan att de brydde sig för mycket om de religiösa riterna och skillnaderna.

Den tredje gruppen, som kom sist och bäst bevarade sin judiskhet var judarna som vandrade in från öst och etablerade sig i rikets nord östra del. Deras invandring började sporadisk redan på 1600-talets andra del, men den stora strömmen kom huvudsakligen efter Polens första delning 1772, när Galizien blev en del av det österrikiska riket. Dessa grupperingar skiljde sig markant från den övriga kristna befolkningen. De bar de traditionella dräkterna med kaftan och hatt, skägg och hår på traditionellt judiskt sätt. De assimilerades och moderniserades mycket långsammare.[3] Det var också de som blev den antisemitiska propagandans huvudsakliga mål. Dessa, mestadels chassidiska, judar flydde fattigdomen från öst och förblev ganska länge fattiga.[4] Deras verksamhet var främst småhandeln och krögeri. Ännu i mellankrigstiden drevs nästan alla små butiker och krogar i dessa områden av judar.

Dessa olika ursprung åstadkom också mycket olika förhållningssätt, särskild i assimilationsfrågan, men också i inställningen till de religiösa och de organisatoriska frågorna. Dessa olika attityder ledde så småningom till konflikter som genererar en splittring inom den ungerska judenheten, som är utan motstycke i judendomens historia[5 ]

Den dominerande inriktningen i de västliga delarna, och speciellt hos medelklassjudarna i 
Budapest och i de flesta städerna, var neologernas. Deras uppfattning var att den förändrade, mer toleranta kristna attityden måste mötas av en förändrad och öppen judisk attityd.[6] Judarna måste ge upp den religiösa bigottismen och följa ett av den moderna utvecklingen dikterat världsligt liv, som de övriga emanciperade kristna levde. De var anhängare av assimilationen och kallar sig gärna ungrare av israelitisk tro och inte judar. Deras organisationer ledds nästan alltid av världsliga personer och hade mycket mindre tendens att reglera medlemmarnas sociala eller religiösa liv. Dessa sekulariserade och assimilerade grupper av medelklassjudar som hade en mycket lös koppling till religionen, blev så småningom de mest inflytelserika i landet.

De östra delarna, som sagts ovan, dominerades av de ortodoxa och de chassidiska judarna med mycket mindre tendens till assimilering och en mera utpräglad judisk identitet. Deras organisationer leddes av rabbiner och det judiska levnadssättet efterlevdes betydligt strängare. De betraktade med stor misstänksamhet neologernas inställning speciellt i religiösa frågor och försökte bekämpa den. Mellan representanterna från dessa två grupperingar var de sociala kontakterna mycket sporadiska även om de befann sig i samma geografiska område eller samma stad. Splittringen manifesterar sig inte bara i de religiösa attityderna. Mellan neologerna och de ortodoxa fanns betydande skillnader även i deras politiska uppfattningar. Neologerna var främst influerade av den ungerska elitens konservativt liberala attityd medan de flesta vänsterradikalerna härstammar från den mera fattiga ortodoxa skikten.

Det fanns mellan dessa två huvudgrupperingar ett mindre antal s.k. status quo-judar som inte ville tillhöra någon av dessa två större sammanslutningar.

\section{Judarna i det ungerska sociopolitiska livet före första världskriget}

Tack vare de positiva reformerna som införs redan på slutet av sjuttonhundratalet växer den judiska befolkningen i den österrikiska monarkien avsevärt. På mindre än hundra år mångdubblades den både i absoluta och relativa tal. Från 80775 personer år 1787 ökade den judiska befolkningen år 1880 tack vare höga födelsetal och en alltmer tilltagande invandring från Östeuropa till 624826 personer, som utgjorde 4,4 \% av befolkningen.[7] I Storungern ökar sedan antalet judar till 911227 år 1910, en siffra som utgjorde nästan 5 \% av den totala befolkningen på runt 21 miljoner invånare. [8]

Ungern fick efter 1867 en bred autonomi inom den nybildade dubbelmonarkin ÖsterrikeUngern, och den ungerska lagstiftningen blev betydligt mera tolerant och liberal.99] Lagstiftarna hade i sikte landets snabba modernisering och borgerliga utveckling. En bieffekt av den toleranta lagstiftningen blev en drastisk ökning av den judiska invandringen från öst - men också en hög assimilationstakt och ungersk lojalism bland judarna i Ungern.

I den liberala eran som följde i Ungern i spåren av denna nyvunna autonomi, som hade sina rötter i den ungerska borgerliga och nationella revolutionen 1848-49, började den ungerska judendomens gyllene år.[10] De fick lika politiska och juridiska rättigheter som landets övriga befolkning och 1895 jämställs det israeliska trossamfundet med alla de övriga.[11] Randolph L. Braham skriver om detta på följande sätt: "After its emancipation in 1867, the Jewish community of Hungary enjoyed an unparalleled level of multilateral development ... as a consequence of the Hungarian policy of tolerance, the Jews considered themselves as an integral part of the Hungarian nation."[12]

Trots regimens aristokratiska och i grund och botten reaktionära karaktär, särskilt mot de andra minoriteterna, upplevde den ungerska judendomen sin guldålder i perioden efter den dubbla monarkins instiftande. Judarnas företagsamhet gjorde att de på några få årtionden lyckades inta avgörande ekonomiska, finansiella och kulturella positioner i landet. Det var en tid av frenetisk uppåtsträvande och en tyst, nästan (o)helig allians verkade fungera mellan den ungerska eliten och judendomens ledande skikt efter 1867.[13] Judarna visade sig vara den minoritet som ivrigast assimilerade sig i den ungerska kulturen och understödde de ungerska strävandena att homogenisera och magyarisera landets mycket 
blandade befolkning.[14] Enligt folkräkningen 1910 var bara något över 54 \% av landets befolkning ungersktalande och hit medräknades också de 77 \% av de över 911000 judarna.[15]

Judendomen assimilerades och magyariserades främst genom sina egna organisationer.[16] De var väl medvetna om att den liberala regimen - som främst representerade den dominerande ungerska befolkningen - var deras främsta sköld mot de antisemitiska manifestationerna. Denna medvetenhet hade som konsekvens att inom den assimilerade judendomen utvecklades starka känslomässiga band mot hemlandet Ungern, och de flesta judarna identifierade sig med de ungerska strävandena. De blev ivriga patrioter och förespråkare av den ungerska hegemonin inom landet.[17] Även inom den judiska intelligentsian - som producerade stora personligheter inom den ungerska litteraturen och kulturen i allmänhet - var de flesta förespråkare av de ungerska nationalistiska intressena. Samtidigt var den ledande ungerska eliten väl medveten om behovet av en borgerlig utveckling. Eftersom man inom den ungerska befolkningen inte var benägen att syssla med de borgerlig-kapitalistiska aktiviteterna betraktades den lojala judendomens avancemang inom den kapitalistiska sektorn med välvilliga ögon. Stora delar av landets industriella och finansiella liv kom på så sätt i judiska händer och detta med regimens stöd och goda minne. Att judarna var, ur moderniseringens och den borgerliga utvecklingens synpunkt, progressiva krafter i samhället och erkändes av många även utanför den politiska eliten. Judarna ledde den liberal-demokratiska rörelsen också, och det demokratiska partiet som grundades i början på 1900-talet hade sin främsta bas bland judarna i Budapest.

Frimurarrörelsen hade en stor andel radikala judiska intellektuella bland sina medlemmar och dessa samverkade med samhällets övriga liberal-demokratiska krafter för en demokratisering av livet i Ungern. Vänsterradikalismen hade också en stor andel judiska intellektuella bland sina representanter, och detta kom sedan att visa sig i deras stora deltagarandel bland ledarna av revolutionerna som följer i första världskrigets spår.

Judarna var starkt närvarande i det kulturella och vetenskapliga samhällslivet. Intressant ur deras identitetssynpunkt var att många av tidningarna eller organisationerna runt sekelskiftet som grundades och leddes av judar inte hade något i deras namn som syftade på detta. Tvärtom, hade de ofta namn som inkluderade orden ungerska, t.ex. tidskriften Den ungerska samhällsvetenskapliga revyn grundad 1900 av framstående judiska samhällsvetare. Namnet på deras bästa litterära tidskrift: Nyugat (Väst) speglade de ledande judiska grupperingarnas politiska och kulturella huvudinriktning. Denna tidskrift samlade förutom judarna som grundade den - den absoluta gräddan av den ungerska litterära och konstnärliga eliten i en samverkan som var fri från antisemitiska övertoner.

Den mest inflytelserika och tongivande delen av judarna var alltså sekulariserade ungrare runt första världskriget, men tillhörigheten till den ungerska nationen var en viktig beståndsdel även i identiteten hos den stora majoriteten av de religiösa judarna. De såg sig själva som ungrare av judisk tro. Samtidigt kan man lugnt påstå att de sekulariserade judarna i Ungern före första världskriget också representerade en stor del av avantgarden för den rationella, internationalistiska och vetenskapliga världsåskådningen i landet. Och de flesta agerade inte som judar utan som en del av den ungerska nationen.

Den förda toleranta politiken det gjorde möjligt för judarna att frenetisk leta sig in i den nya växande borgarklassen och de fria yrkena. På så sätt blev de kraftig överrepresenterade i den skolade medelklassen. Judarnas andel bland studenterna på universitet och högskolor var över 30 \% och 20-50 \% inom de fria yrkena. Denna andel var enorm jämfört med deras totala andel i befolkningen på bara 5-6 \%.[18]

En annan effekt av den toleranta politiken blev att den judiska majoritetens ungerska patriotism lämnar mycket lite plats till sionismens utbredning. Sionismen var ganska impopulär bland Ungerns judar i alla grupperingar. Sionismens grundare, Theodor Herzl, själv född i Budapest, visste varför och på den sionistiska världskongressen i Basel, 1897 sade han: "I denna antisemitiska värld hade vi bara två oaser: Storbritannien och Ungern." Och detta var därför hans berömda uttalande "Wir sind ein Volk, ein Volk" ingenstans 
Men judarnas väldiga och snabba avancemang inom landets ekonomiska och kulturella liv skapade så småningom en livlig debatt och en antisemitisk motreaktion och propaganda som, trots regimens snabba och hårda motåtgärder, lämnade latenta men djupa spår i den ungerska allmänna opinionen.[20]

Samtidigt var en del av de judiska intellektuella - trots deras höga assimilationsgrad och patriotism - mycket mindre benägna till nationalism än den övriga befolkningen. Många av de judiska vänsterintellektuella bortsåg från styrkan som fanns i de nationella och konservativa strömningarna som alltmer fick övertaget i landet ju närmare det första världskriget man kom. De litade för mycket på rationalismen även när den nationella katastrofen kom i krigets spår, och detta var ett stort misstag. De kom att begå detta misstag när för många av dem anslöt sig till Béla Kuns kommunistiska regim som kom till makten den 21 mars 1919, och även lägre framåt när de inte ville inse att en regim som den nazistiska kunde begå helt irrationella handlingar som motsade varje västerländsk rationalism. Första världskrigets slut satte punkt på den liberal-rationella utvecklingen i Central- och Östeuropa och med detta satte punkt även på judarnas guldepok.

\section{Ungern, judarna och fredsavtalet vid Trianon}

Axelmakternas nederlag i det första världskriget medförde den största nationella katastrofen i Ungerns historia sedan nederlaget mot turkarna vid Mohács, 1526 och den påföljande tredelningen av riket 1541 .

Efter vapenstilleståndet i november 1918 upplöstes den mångnationella österrikiskungerska armén helt. Samma månad utbröt i Ungern en borgerlig-liberal revolution som proklamerade landets utträde ur dubbelmonarkin och avsatte konungen. Denna s.k. stockrosrevolutionen, ledd av den västvänlige greven Károlyi väckte få protester utanför landet. Men på våren 1919 övergick denna borgerliga omvandling i en kommunistisk revolution med en röd terror som så småningom följde i dess spår. Revolutionens ledare bad den sovjetiska röda armén om hjälp och detta framkallade segrarmakternas ingripande.[21] De gav mandat till de tjeckiska och rumänska arméerna - som redan var stationerade vid demarkationslinjer innanför Ungerns gränser - att ingripa och slå ner revolutionen. Efter kortvariga framgångar besegrades den hastigt mobiliserade ungerska röda armén av den flerfaldiga övermakten och den rumänska armén ockuperade och plundrade Budapest.[22] Dessa dagar beskrivs som Ungerns svartaste i de ungerska historieböckerna. Förödmjukelsen var total. Med den föraktade rumänska armén i Budapest blev Ungern fullständigt överlämnat till segrarmakterna och utan någon möjlighet att opponera sig mot deras fredsvillkor. Fredsavtalet som undertecknades i Trianon 1920 tvingade Ungern att avträda 2/3 av sitt territorium och förlora över 10 miljoner (av vilka över 3 miljoner ungrare) av sin ursprungliga befolkning som före kriget var över 18 miljoner.[23]

Den nationella katastrofen öppnade vägen till letandet efter syndabockar, och den antisemitiska propagandan, som bromsades före kriget av regimen, började växa och få allt större betydelse.

Trots att landets uppdelning var beslutad redan innan den röda revolutionens nederlag knöt folkopinionen - felaktig men verklighetsskapande - denna katastrof till judarna. Béla Kun, den röda revolutionens ledare, var jude och de flesta av hans ministrar var också judar. Många av de s.k. Leninpojkarna som reste runt i landet för att - med ganska hårda metoder - "stärka den revolutionära andan" bland bondebefolkningen, var också judar.[24] Detta förde med sig att den följande kontrarevolutionära reaktionen fick en stark antisemitisk prägel, och antisemitismen fick näring under hela perioden mellan de två världskrigen. De flesta ungrare ansåg att landet kunde utverka bättre fredsvillkor utan den röda revolutionen som judarna beskylldes för. Reaktionen blev grym och präglades av en nästan fanatisk antibolsjevism och antisemitism.[25] Tusentals arresteringar genomfördes - inte bara mot 
judar förstås - och över 100 dödsdomar förkunnades och 74 av dessa verkställdes. Ett stort antal framstående judiska vänsterintellektuella tvingas på flykt.[26] Denna antibolsjevism och antisemitism kom, med vissa lugnare perioder, att prägla den ungerska regimen i hela perioden som slutar med Ungerns militära nederlag i andra världskriget.

Den nya attityden mot judarna gjorde att obalansen i de ungersk-judiska relationerna inom medelklassen började ännu starkare uppmärksammas efter det första världskriget. Allt fler röster började höras om "det judiska problemet" i Ungern och om att judarnas dåliga påverkan på det ungerska samhället bestämt måste begränsas. Detta var också en period när uppfattningen om judarna som en egen ras börjar slå rot i allt större kretsar i Ungern. Ändå fick den ungerska antisemitismen omedelbart efter världskriget främst en nationell prägel, och de rasistiska tankarna slog igenom först i slutet av 30 talet, och då främst under tysk påtryckning.

Men i Ungern gjordes en avgörande skillnad mellan jude och jude. Det blev främst de nyinvandrade judarna eller de vänsterintellektuella som gärna betecknades som utlänningar, som icke assimilerade "galizier" som ansågs vara mer till skada och till en börda för den redan så hårt slagna nationen. Denna identifiering gjordes villigt även av den stora majoriteten av de sekulariserade och assimilerade judarna som ville betrakta sig främst som "ungrare av israelisk trosbekännelse" med minimala beröringspunkter med dessa "galizier".[27] Dessa assimilerade judar vägrade tro att guldepoken tog slut även för dem. Den senare framgången med vilka deportationerna 1944 genomfördes förklaras av många historiker genom "the furious anti-Semitic tide that swept over the country's cultural and political landscape during the interwar period" kombinerad med judarnas fortsatta tillit på den ungerska regimen - trots att den kontrarevolutionära reaktionens portalfigur, amiralen Miklos Horthy var en, om även moderat, antisemit.[28] Varför bevarades denna tillit?

\section{Den ungerska inrikes- och utrikespolitiken i mellankrigsperioden}

Efter amiral Miklos Horthys maktövertagande och den påföljande vita terrorn, den anstormande antisemitismen gav 1920 upphov till den första antijudiska lagen i Europa i denna period (se nedan) och även kommunistpartiet förbjöds. Trauman som landet genomgick efter fredsavtalet vid Trianon och efter minoriteternas "svekfulla" uppträdande lämnade djupa spår i folkpsyket. Paranoian och misstänksamheten mot allt som inte var ungersk i landet ökade. Nationalismen och irredentismen blev de viktigaste beståndsdelarna i den nya ideologin som växer fram. Övertygelsen bara ökade att det var de icke ungerska elementens vändning mot "det tusenåriga ungerska riket" som drev landet i katastrofen och att bara genom att rensa Ungern från allt som inte var ungersk - eller åtminstone genom att ta makten ifrån dem - kan landet igen återuppstå. Denna nya ungerskhet kunde definieras som nationalistiskt, konservativt, kristet och, som en logisk konsekvens, antisemitiskt. Att de forna allierade, judarna med Béla Kun i spetsen, deltog i så hög grad i den ödesdigra röda revolutionen var ett tydligt bevis på att det inte gick att lita på dem.

Men den förste ministerpresidenten som regerar en längre tid efter de oroliga tiderna mellan 1921 och 1931 - greve Stefan Bethlen, var en pragmatiker förutom att han var en typisk representant för den gamla aristokratiska ledningen. Den största delen av den gamla moderata aristokratin som återkom till makten med premiärministern greve Bethlens regering stödde Bethlens politik. De insåg att i landets dåvarande situation skulle en glidning mot extremism leda till ännu värre följder och bromsa utvecklingen. Bethlen kompromissade med socialdemokratin och en viss politisk avspänning inträdde som även judarna hade mycket att vinna på.

Rädslan för kommunismen - och sedan också för den växande högerextremismen efter det nazistiska maktövertaget i Tyskland - gjorde att det konservativa ledarskiktet med Horthy i spetsen inför en alltmer auktoritär regim. Ändå menar Maria Kovács att jämfört med Italien och Tyskland var Ungern "a somewhat special case ... Unlike those countries, Hungary did not embark on a dictatorial path in the interwar period. Despite its defeat in World War I, 
two leftist revolutions in 1918 and 1919, and a rightist counterrevolution in 1920, this country managed to rescue a measure of its old fashioned liberal traditions and to reconstruct a parliamentary regime that, though far from being a model of political democracy, still survived...until the German occupation of the country in March 1944."[29]

Regeringen hårdbevakade både vänster- och högerextremismen och det fascistoida pilkorspartiets ledare, överste Szálasi blev upprepade gånger dömd och fick sitta i fängelse. Vänsterextremismen straffas ännu hårdare. Kommunisternas samarbete med sovjetryssarna var det värsta som den dåvarande ungerska regeringen - eller domstolarna - kunde tänka sig och många av kommunistpartiets medlemmar fick också sitta långa år i fängelse. [30] Det socialdemokratiska partiet fick utstå en rad trakasserier men förbjöds aldrig, trots att: "by 1944, a free and legal social democratic party was a striking anomaly in the German dominated Europe".[31]

Trots denna inre balanspolitik var Ungern vid denna period redan både utrikespolitiskt och ekonomiskt stark beroende av Tyskland. Utrikespolitikens absolut högsta mål att åtminstone delvis återfå de förlorade territorierna, och det faktum att Tyskland var det enda land som ville och kunde effektiv stödja denna politik gav egentligen inga riktiga valmöjligheter. Münchenöverenskommelsen 1938 mellan Tyskland och Västmakterna öppnade vägen mot denna målsättnings förverkligande. Den innehöll en klausul om de ungerska minoriteterna som tvingade Slovakien - och senare Rumänien - att börja förhandla med Ungern om en lösning kring gränsterritorierna som hade ungersk majoritetsbefolkning. Ungern fick tillbaka ett territorium på $11927 \mathrm{~km}^{2}$ med över en miljon invånare med en absolut ungersk majoritet. Den tyska medlingen i denna återförening gjorde att den allmänna opinionen blev avgjort tyskvänlig, och detta påverkade även den ungerska inrikespolitiken. Senare, i samband med Tjeckoslovakiens upplösning på våren 1939, togs även delar av Ruteniet tillbaka. Detta var ett territorium som tillhörde det historiska Ungern men hade inte någon ungersk majoritet.

Trots att det fanns starka krafter inom det ungerska ledarskiktet, med Horthy och Teleki i spetsen, som försökte undvika en för nära allians med Tyskland och hålla dörren öppen även mot Storbritannien, blev denna politik ingen större succé.[32] Det tyska inflytandet i hela det ungerska samhällslivet, särskild efter Anschluss 1938 då Tyskland blir granne med Ungern, blev för stor. Ekonomin dominerades av relationerna med Tyskland, och 1939 gick över hälften av den ungerska handeln mot den nya stora grannen i väst. Detta beroende lämnade sina tydliga spår i den inrikespolitiska maktbalansen som var ofta styrd av de tyska kraven som ställdes mot de ungerska politikerna. Tyskland hade också andra, utrikespolitiska möjligheter att påverka den ungerska inrikespolitiken. Dessa kom främst genom de fortsatta ungerska ansträngningarna att återfå resten av de 1920 förlorade territorierna. Efter Frankrikes fall 1940 öppnades möjligheten att ta upp Transsylvaniens fråga med Rumänien. Förhandlingarna mellan den ungerska och den rumänska regeringen som inleddes på tyskt initiativ på sommaren 1940 strandade och båda länderna ber stormakterna Tyskland och Italien att medla. Förhandlingarna inleddes på nytt i Wien och ett nytt kompromissbeslut antas i augusti 1940 som gav Ungern tillbaka norra Transsylvanien med en ungersk majoritetsbefolkning men också med en betydande rumänsk minoritet. Den allmänna glädjen över denna framgång och över det som ansågs som tysk generositet mot Ungern - och rädslan att inte förlora de tillbakavunna territorierna - drev Ungern ännu djupare in under den tyska politikens inflytande.

\section{Den ungerska judendomen i mellankrigstiden och den ungerska judepolitiken i denna period}

Judarnas andel i totalbefolkningen efter Trianon ökade inte nämnvärt men deras andel ökade i städernas befolkning. På det sättet blev de också mer synliga för makten. Den absolut största majoriteten av judarna levde i städer och runt $15 \%$ av storstädernas befolkning var av judiskt ursprung. I Budapest, av stadens befolkning på nära 1 miljon, var över $23 \%$ judar (56 \% av den judiska befolkningen bodde i Budapest). Denna 
koncentration förklarar delvis deras kraftiga överrepresentation på universiteten och högskolorna och i de s.k. fria yrkena. År 1920 var över 50 \% av juristerna, 45 \% av läkarna och runt $15 \%$ av de privatanställda ingenjörerna i Ungern judar. Parallellt med att denna situation alltmer uppmärksammades dök ett annat problem upp. Efter fredsavtalet i Trianon flydde ett allt större antal intellektuella till moderlandet från de avträdda territorierna, en situation som skapade ett överskott av akademiker med stor arbetslöshet bland intellektuella som följd.[33]

Den växande antisemitismen fick på så sätt ny näring och paranoian som dominerade efterkrigsperioden gjorde att judarna utpekades som ett problem även ur denna synpunkt. För att tillfredsställa denna antisemitiska stämning antas 1920 en ny lag som införde en s.k. numerus clausus i antagningen på landets universitet och högskolor. Detta betydde att varje folkslag skulle få en för deras andel i totalbefolkningen proportionell antal platser vid antagningen och inte mer.[34] Judarna fick alltså bara $6 \%$ av platserna. Lagen slår, utan att direkt och öppet vara riktad mot judarna, hårdast mot dem.[35] Högerextremisternas krav på direkta diskriminerande åtgärder mot judarna tillbakavisas av regeringen ledd av greve Paul Teleky och inte ens lagen om numerus clausus efterlevs med någon större stränghet.[36] Merparten av befolkningen och särskilt utlandet slogs med häpnad av dessa allmänna antijudiska bestämmelser som stred mot fredsföredragets bestämmelser om minoriteterna.[37] De ungerska judarna tillbakavisade all yttre inblandning i dessa bestämmelser. Deras ledare hade förblivit ungerska patrioter, och judarna ville inte att de skulle betraktas som en minoritet även om detta skulle ha inneburit att de föll under fredsföredragets skydd. De deklarerade att de var en del av den ungerska nationen och ville bevara de goda relationerna med det ungerska samhället och ville inte dra fördelar genom ett fredsföredrag som slog sönder deras hemland.[38] Och de verkade ha rätt. Den nästkommande premiärministern, greve Bethlen, var en realpolitiker trots att han själv var antisemit. Han insåg att det högsta utrikespolitiska målet: revisionen av fredsavtalet från Trianon var omöjligt att uppnå utan en inre ekonomisk konsolidering. Han, som många av sina ledarkolleger, insåg att detta inte kan realiseras utan det inre och yttre judiska storkapitalets hjälp. Så han var beredd att åsidosätta sina personliga känslor för att förbättra relationerna med judenheten. På så sätt, trots den tilltagande antisemitismen, återskapades de vänliga relationerna mellan aristokratin och den judiska storbourgeoisien. Allt började likna situationen före kriget. Den judiska storbourgeoisien accepteras igen som tyst partner i ledarskapet. Horthy spelade ofta bridge med dess representanter.[39]

Resultatet av detta samarbete började så småningom visa sig även i den inrikespolitiska situationen. De högljudda antisemiterna tystas, och 1928 upphävs de diskriminerande klausulerna i numerus clausus bestämmelserna. Efter det, under en tioårsperiod, antas inga antijudiska bestämmelser.[40] Judeproblemet begränsades främst till diskussionerna om den tilltagande judeinvandringen från öst, och de samhälleliga problemen som skapades av denna invandring. I detta avseende var den assimilerade och etablerade judendomens inställning mycket lik regeringens; båda vill begränsa denna invandring. Oron som skapades av dessa främlingar gjorde att regeringen redan 1925 fick fullmakt från parlamentet att efter egen bedömning utvisa alla främmande element som visade sig vara skadliga för landet. 1930 blev alla främlingarna i landet speciellt bokförda och en speciell institution som tog hand om deras ärenden skapades.[41]

Detta relativa lugn i inrikespolitiken och i judefrågan började allvarligt naggas i kanten på grund av den sociala oron som skapades i kölvattnet av den ekonomiska krisen som började runt 1930 i Ungern. Denna oro ledde så småningom till Bethlen regeringens fall och regeringsmakten kom 1932 i före detta högerextremisten och nazisympatisören Gyula Gömbös händer.[42] Gömbös, som visade sig vara en pragmatisk politiker, höll sig till sina löften och fick på det sättet det judiska kapitalets fullhjärtade stöd i den ekonomiska konsolideringen efter krisen, och konsolideringen betydde att även hans egen position konsoliderades. Judarna, som fortfarande troget deklarerade sin enhet med det ungerska folket och även bad den amerikanska judendomen att stödja Ungerns revisionistiska strävanden, luras i fällan.[43] Ty, trots vapenvilan med judarna, var Gömbös en helhjärtad Tysklandsvän och hans regering medförde att ett allt större antal likasinnade fick viktiga 
positioner inom den statliga administrationen. Samtidigt utvecklade han, med sin fascistoida propaganda, ett brett stöd för sina idéer främst inom den lägre medelklassen och i den, av stor arbetslöshet fortfarande plågade intelligentian, något som senare fick avgörande betydelse för landets öppenhet inför tysk påverkan.[44] Hans planer vävda tillsammans med Hermann Göring om att göra Ungern till en fascistisk stat förhindrades förmodligen bara av hans plötsliga död 1936. Under hans regeringstid bildades en rad naziliknande högerextremistiska partier och deras antisemitiska propaganda fick en allt bredare lyssnarskara. Det tyska inflytandet inom landet kunde inte längre uppvägas - trots försök från de följande regeringarna och aristokratin. Men den tyska lösningen på judefrågan accepteras inte, inte ens efter det att Tyskland börjar visa fortsatt stöd för den ungerska revisionismen.[45]

De ungerska judarna kände inte igen den nalkande faran och fortsatte visa fullt förtroende för landets ledare. Många av dem var även beredda att bortförklara den växande antisemitismen som förståelig med tanke på vissa judars svekfulla agerande i de svåra tiderna efter det första världskriget.[46] Huvudlösningen för de flesta och mest tongivande judarna var fortfarande att göra den judiska närvaron i landet så osynlig som möjligt genom en nästan fullständig social och kulturell assimilation. Judarna måste bli riktiga ungrare som bara skiljer sig religiöst från andra ungrar. Den dominerande uppfattningen uttrycks på följande sätt av landets kanske mest inflytelserika jude, ordföranden i det israelitiska samfundet i Budapest, Samu Stern: "Judendomen var sen 2000 år tillbaka bara en religion och inte en nation eller nationalitet ... Vi hade alltid sagt att den ungerska judenheten var och kommer alltid att förbli en organisk del av den ungerska nationen. Vi kommer att driva vår aktivitet i denna anda, alltid till samfundets och landets fördel. I Ungern hade det aldrig existerat - och skulle aldrig existera - ett separat judiskt parti, ty medlemmarna av det judiska religiösa samfundet vill inte bli andra än ungrare av judisk tro som - genom att bevara sin religiösa trohet - vill fullfölja sina rättigheter och skyldigheter".[47] Den ovan uttryckta ståndpunkten beskriver ganska väl ställningstagandet hos medlemmarna i alla de judiska samfunden i Ungern, något som gjorde att sionismen förblev obefintlig i Ungern även efter Trianon. Något mera utbrett var sionismen i de avträdda delarna och speciellt i Transsylvanien, och därifrån kom den till Budapest också efter återföreningen i augusti 1940.

\section{Judelagarna och den ungerska judepolitiken efter Anschluss}

Efter Anschluss blev det klart att Ungern inte kunde ha en helt oberoende politik gentemot Tyskland. Också den inre nazistiska högerextremismens tryck på regeringen var större än någonsin. Två månader efter Anschluss, när Tyskland blev landets enorma granne, antas den första judelagen.[48] Den begränsade bland annat judarnas andel i de s.k. fria yrkena och bland de anställda i bank- och affärsverksamhet till max. $20 \%$. En frist på fem till tio år ges för förverkligandet av lagens bestämmelser. Runt 15000 judar berördes av denna lag som ändå betraktas som mild jämfört med judelagarna i de övriga länderna i Mellaneuropa. [49] Judarna själva, som var medvetna av den tilltagande betydelsen som "det judiska problemet" började få i samhället, var beredda att acceptera dessa mildare begränsningar för att ta loven av högerextremisterna. De ville inte ens att utlandet intervenerade till deras fördel.[50] Men denna mildhet upphörde i maj 1939 då den andra judelagen antogs. I det hårdnade inrikes- och utrikespolitiska klimatet godkändes - trots betydande opposition - en lag som starkt försvårade judarnas situation. [51] Medan den första lagen definierade judarna ur konfessionell synpunkt får judarna i den nya lagen också en rasistisk definition. Även en del av dem som konverterade till kristendom efter 1919 betraktades som judar.[52] Historikern Maria Kovács sammanfattade väl essensen i denna andra lag:

The new law withdraws some basic political and civil rights by restricting the exercise of the franchise to members and descendents of Jewish families with a record of domicile in the Hungarian Kingdom before 1867. The law stipulated a gradual removal of Jews from the judicial bench and public education over the course of five years. Jews were allowed to be editors only 
of Jewish newspapers and were not permitted to be directors of theatres. The government-set ceiling of Jews in intellectual occupation was to be gradually reduced to 6 percent. A 6 percent ceiling was imposed on trading licences in Jewish hands so that no new licenses could be granted to Jews until the proportion was reduced to 6 percent. In commerce and industry, the law set a $12 \%$-ceiling on the proportion of salaries paid to Jews by any firm. The proportion of public contracts awarded to Jewish firms was also to be reduced to 6 percent. The right of Jews to ownership of land was restricted.[53]

Ungefär 200000 personer berördes av lagen men den praktiska tillämpningen var mycket varierande. Till skillnad från Tyskland fanns ju ingen diktatur i Ungern och de ansvariga myndigheterna eller institutionerna var ofta beredda att se mellan fingrarna.[54] Det judiska samfundet försökte nu försvara sig. Budapest samfundets ordförande Samu Stern åkte till London för att be om hjälp från judarnas världsorganisationer och uppmanade dem att försöka övertyga regeringarna i England och USA om att intervenera. Framgången uteblev.[55] Båda ansåg att en intervention för att hjälpa judarna bara skulle skärpa Tysklands attityd och driva Ungern ännu närmare tyskarna. Lagen slog i alla fall aldrig så hårt som den var tänkt, och detta faktum kom att ge extremhögern tillfälle att starkt kritisera regeringen. Den ungerska politikens glidning mot extremhögern fortsatte i takt med de tyska framgångarna. Extremhögerns oroväckande agitation mot judelagarnas slappa tillämpning, och det ökade tyska beroendet och trycket ledde i juli 1941 till genomdrivandet av den tredje judelagen.[56] Den var rent rasistisk och siktar nästan uteslutande till att försvara ungrarnas "rasrenhet". Den förbjöd bl.a. giftermål eller sexuella relationer mellan kristna och judar. Lagen kungjordes i augusti 1941, trots det att överhuset i parlamentet först avslog lagen och trots de starka protesterna, speciellt från de kyrkliga ledarnas sida. Genom lagens kungörelse hade judarnas uteslutning ur samhället som en onyttig och lägre stående ras genomförts.

Men detta räckte inte för de tyska nazisterna som pressade på regeringen för ytterligare åtgärder mot judarna. I landet bodde tusentals judiska och icke-judiska flyktingar från de tyskockuperade länderna som stark irriterade tyskarna.[57] För att blidka dem beslutades då arresteringen och överlämnandet av över 16000 judar som befann sig i Ungern som flyktingar och inte hade ungerskt medborgarskap. Tyskarna tog emot dessa judar och dödade runt 12000 av dem i en massaker i Kaminits-Podolsk i Polen i augusti 1941. Men den ungerska regering hade inte några kriminella intentioner med överlämnandet och när uppgifterna om massakern nådde Horthy och den ungerska regeringen stoppade inrikesministern Keresztes-Fischer alla deportationerna. I Ungern fanns då runt 100000 judiska flyktingar som låg i farozonen för deportation.[58] Men andra åtgärder, som kom att kosta tusentals judars liv, speglade den hårda antijudiska atmosfären. Lagen om den obligatoriska arbetstjänsten 1939, som från början var avsedd för alla som ansågs som inte lämpliga för vapentjänst och som främst riktades mot vänsterradikaler, användes nu nästan uteslutande mot judarna. Efter 1941 ansågs alla judar som opålitliga och olämpliga för vapentjänst. Denna allmänna misstänksamhet och de inkallade judarnas rättslöshet ledde till att många ohyggliga övergrepp begicks mot dem.[59]

\section{Underblåst av det tyska stödet ökade den antisemitiska hetsen inom extremhögern och} deras representanter blev alltmer högljudda. [60] I denna oroliga atmosfär bestämmer sig den moderata eliten med Horthy i spetsen att bromsa den farliga utvecklingen. De insåg att nazisterna var mycket farligare för deras fortsatta maktställning än judarna. Den nye premiärministern, aristokraten Miklos Kállay, insatt i mars 1942, ville återinföra lag och ordning. Som en följd av det tyska trycket, implementerade han de judiska lagarna men försäkrade sig om att inga övergrepp skedde. De ansvariga för en massaker som skedde efter ungrarnas intåg i Jugoslavien ställdes inför rätta.[61] Samtidigt gav den stränga tillämpningen av de judiska lagarna förevändning för Kállay att vägra införa de mera radikala åtgärderna som Tyskland konstant krävde.[62] Han vägrade även gå med på tyskarnas krav att låta judarna med ungerskt medborgarskap som levde inom Tredje rikets territorium underställas samma behandling som de tyska judarna. En av hans slående 
motargument var att om tyskarna påstår att judarnas definitiva eliminering ur det ungerska samhället var ett omedelbart ungersk intresse då borde samma intresse diktera en snabbare assimilering av de ungerska tyskarna som var Tredje rikets femte kolonn i Ungern.[63]

Situationen stabiliserades även runt de icke ungerska judiska flyktingarna på Kállays tid. World Jewish Congress representant i Genève, dr Abraham Silberschein rapporterade till Washington att: "I have established good connections in Hungary with governmental circles, and the refugee questions are gradually being settled there in a way which is even more favorable (sic) than in Switzerland."[64]

Men Kállays bestämda hållning i judefrågan, kombinerad med hans strävanden att dra Ungern ur kriget föranledde till slut tyskarnas ingripande. Den 19 mars 1944 invaderade den tyska armén Ungern. Trots flera varningar från den ungerska underrättelsetjänsten och varningar från agenter från Abwehr överraskades både Kállay och det judiska samfundet av den tyska inmarschen som definitivt satte punkt på den relativt fridfulla tillvaron för de ungerska judarna.[65]

\section{Mot Förintelsen}

Redan första dagen ockuperades alla järnvägstationerna av tyskarna som arresterade alla judar som de hittade där. Sedan infördes ett totalt reseförbud för judar. Nästan samtidigt med judarna arresterade tyskarna alla de ungerska politikerna och framstående personer som kunde misstänkas vara oppositionella.[66] På det sättet blev de antinazistiska krafterna, som hade starka positioner före invasionen, helt förlamade ett bra tag framåt. De moderata politikerna som undkom arresteringen, som den tidigare så inflytelserike f.d. premiärministern, greve Bethlen, fick gömma sig och kunde inte handla medan den gamle Horthy undvek att kommunicera med den nytillsatta regeringen.[67] Omedelbart efter inmarschen tvingades premiärministern Kállay att lämna ifrån sig makten och söka skydd på den turkiska legationen. Den 24 mars formades en ny regering med högerextremister i majoritet. Denna regering kom att ge sitt fulla stöd till tyskarna för implementeringen av Den slutgiltiga lösningen även i Ungern.[68] Premiärminister blev den före detta Berlinambassadören Döme Sztójay, som hade tyskarnas förtroende. Sztójays Quislingregering utförde först - på tyskarnas uppmaning - en omfattande rensning inom den statliga administrationen och avlägsnade alla politiker och tjänstemän som misstänktes ha antinazistiska känslor.[69] Några befattningshavare avgick senare, i protest mot behandlingen av judarna, men resten av den utrensade administrationen var nu lydig och verkställde allt som ålades den. Det värsta problemet för judarna med denna nya regering var att den gamle Sztójay, som var lydig tyskvän men inte någon extremist, saknade respekt hos sina underordnade, särskilt på inrikesministeriet. Inrikesministern, nazisympatisören Andor Jaross hade tyskarnas fulla stöd. Tyskarnas man, statssekreteraren László Endre får total fullmakt att hantera judefrågorna. Han, tillsammans med statssekreteraren och pilkorsaren Baky och gendarmeriöversten Ferenczy, som hade befälet över gendarmerikontingenten som utkommenderades för att stödja tyskarna i hanteringen av judefrågorna, fick härja fritt i provinsen. Tyskarna, med det tyska rikets befullmäktigade i Ungern, Edmund Veesenmayer, i spetsen och Adolf Eichmann som judeexpert, satte igång Den Slutliga Lösningen med fruktansvärd skicklighet och hastighet.[70] De fick Sztójay regeringens fulla stöd.

Eftersom förskräckliga rykten spreds bland judarna i Ungern om vad som hade hänt med de andra judarna i de tyskockuperade områdena i Europa, var det första som Eichmanns förbundna gjorde att försöka lugna ner dem, övertyga dem om att det som hade hänt med de andra judarna i Europa inte skulle hända dem. Tyskarna gav order till den dåvarande judiska ledningens representanter att möta dem redan den 20 mars, den andra dagen efter deras inmarsch i Ungern. Den förvirrade judiska ledningen försökte kontakta inrikesministeriet men därifrån fick de beskedet att "allt som tyskarna kräver måste verkställas."[71] Krumey och Wisliceny, som mötte judarna nästa dag, var mycket artiga. De lovade att inga deportationer kommer att ske, att ingen kommer att behandlas illa bara 
på grund av sin judiska börd, bara de gjorde allt det som tyskarna kräver. De var mycket artiga också medan de gav order till formeringen av en judisk myndighet under ledning av ett judiskt råd, ett Judenrat, som skulle överordnas hela den ungerska judenheten.[72] De meddelade samtidigt att alla de judiska frågorna i Ungern underställs tyskarna och gav i uppdrag till de närvarande judarna att presentera två listor: en på de viktigaste judiska ledarna och de mest inflytelserika personerna och en annan på de fastigheter som fortfarande fanns i judisk ägo. De lyckades så väl i sin lugnande roll att en av de närvarande judarna ringde sin fru efter mötet och sade att: "det är ingen fara, tyskarna vill även hjälpa oss."[73] Men snart visade tyskarna sina verkliga intentioner. I slutet av mars fråntogs judarna alla sina medborgerliga rättigheter och de judiska tillgångarna konfiskerades. Den 29 mars kom ordern om att alla judarna måste bära den gula stjärnan, judarna avlägsnades från alla posterna i det ungerska samhällslivet, de judiska fonderna i bankerna frystes och rörelsefriheten inskränktes.[74]

I början av april deklarerades östra Ungern som krigszon och, som en "säkerhetsåtgärd" började judarnas ghettoisering i detta område. Ghettoiseringen fortsatte sedan i resten av landet, utom i Budapest. Den 14 april rapporterade Veesenmayer till Ribbentrop att Sztójay hade godkänt deporteringen av 50000 arbetsdugliga judar för arbete i Tyskland och lovade att ytterligare 50000 kommer att ställas till tyskarnas disposition i maj.[75] Men det blev inte så som Sztójay föreställde sig. Eichmann och hans ungerska kumpaner Baky och Endre bestämde i en konferens på inrikesministeriet den 14 april alla judars deportering. Under ledning av Eichmann och pilkorsarna representerade av statssekreterarna Endre och Baki startades deporteringarna i mitten av maj i de mest avlägsna, östliga delarna av landet och omfattade alla judarna utan undantag. Speciellt utvalda gendarmerienheter med ett stort antal gendarmer av tyskt ursprung, under befäl av överstelöjtnanten Lászlo Ferenczy, som hade starka pronazistiska känslor, ställs till tyskarnas förfogande.[76] Ingenstans i Europa gick deporteringen så fort. På knappt två månader, mellan den 15 maj och 8 juli 1944, deporterades 434351 judar under grym behandling från Ungern.[77]

Men motståndet började växa. Mellan den nytillsatta regeringen och Horthy - och även inom själva regeringen - fanns starka motsättningar om judefrågans lösning. Trots att Horthy gav fria händer till regeringen i lösningen av judefrågorna och inte ville veta om dessa åtgärder, och trots att tyskarna försökte göra allt för att utestänga honom från det övriga regeringsarbetet också, når allt tätare uppgifter honom om judarnas grymma behandling.[78] Under trycket av sin omgivning i palatset, som var i ständigt kontakt med medlemmar av det judiska rådet, och han informerades om grymheterna med vilka judarna behandlades på landsbygden. I takt med att deportationerna närmade sig Budapest började Horthy visa ett allt starkare intresse för judefrågorna och uttrycka sitt tydliga missnöje över sättet hur judefrågan sköttes. I slutet av maj krävde han från Hitler att Gestapo drogs tillbaka från Ungern. När denne vägrade skrev han ett energiskt brev till Sztójay där han anklagade regeringen för dess sätt att hantera judefrågan och påpekade för Sztójay att deportationerna och grymheten med vilken de genomfördes, inte motsvarade det ungerska sinnet och intressena.[79] Horthy krävde åtgärder mot de ansvariga för dessa grymheter och att Baky avskedades och Endre förflyttades. När rapporterna om deportationernas grymhet blev fler och när i mitten av juni även den senare så berömda Auschwitzprotokollen nådde palatset började Horthy agera.[80] Han påverkades också starkt av de tilltagande protesterna från in- och utlandet. Inom landet inlämnade de protestantiska kyrkornas representanter en protest mot deportationerna redan den 20 juni, och det judiska rådet sände den 23 juni en vädjan till Horthy i vilken de beskrev grymheterna och de otaliga övergreppen som begicks mot judarna.[81] Den katolska ärkebiskopen Justinian Serédi, som intervenerade flera gånger hos Horthy för judarnas skull, hotade nu premiärministern med uppläsandet av ett pastoralbrev som fördömde deportationerna i landets alla katolska kyrkor. Sztójays svar till Szerédi den 19 juli och sättet som han tog upp saken med den påvlige nuntien den 7 juli visar den stora betydelsen som han tillmätte detta hot.[82]

Horthy utsattes för påtryckningar av sin direkta omgivning i palatset och även hans son pressade honom att agera.[83] Från utlandet kom protester från påven, president Roosevelt, 
den svenske kungen, Storbritanniens utrikesminister Antony Eden, ärkebiskopen av Canterbury och den amerikanska senaten.[84] Påven och den svenska kungen vädjade för deportationernas upphörande i slutet av juni, och president Roosevelt hotade med att det kunde få allvarliga konsekvenser efter kriget.[85] Den försämrade tyska krigssituationen efter den allierade landstigningen spelade också en avgörande roll i att väcka den ungerska oppositionens mod. Så redan på kabinett mötet den 21 juni bröt ett gräl ut mellan den biträdande utrikesministern Jungerth-Arnóthy, som hade flera bevis för gendarmernas grymheter och som krävde deportationernas upphörande, och inrikesministeriets representanter, som förnekade anklagelserna.[86] Eftersom inga beslut togs på regeringsmötet, sammankallade Horthy kronkonseljen den 26 juni. Där utryckte han, upprörd, sin tydliga vilja att deportationerna skulle upphöra. Men ännu ville han inte gå emot tyskarnas bestämda vilja ty, sade han, faran för en fullständig tysk maktövertag fanns fortfarande kvar. Samtidigt krävde han bestämt att statssekreteraren Baky avskedades och Endre fråntogs ansvaret för judefrågorna.[87] Slutligen antogs i regeringsmötet den 28 juni ett beslut om grymheternas omedelbara upphörande, och det beslutades att statssekreterarna László Baky och László Endre ifråntogs ansvaret för judefrågorna. Men, med hjälp av Veesenmayers bestämda stöd, fick dessa behålla sina poster. De började även koncentrera gendarmeristyrkor i Budapest för att förbereda en statskupp mot Horthy och för att sedan påbörja deportationerna även i huvudstaden.[88] Arméns underrättelsetjänst varnade Horthy och den utmanade regenten svarade med inkallandet av lojala arméstyrkor i Budapest som förde bort gendarmerna och den 7 juli stoppade han deportationerna.[89] En tydlig motsättning i judefrågan och dess lösning fanns alltså mellan den ungerska moderata ledningen med Horthy i spetsen och de tyskstödda högerextremisterna i regeringen, en osämja som var starkt tillspetsad när Raoul Wallenberg den 9 juli kom till Budapest.

Horthy och de moderata politikerna lättade så småningom alltmer på judarnas desperata situation. De neutrala diplomaternas aktivitet i Budapest bidrog också till denna avspänning. Men den 15 oktober, efter Horthys misslyckade försök att ta Ungern ut ur kriget, kom makten i Ungern med tyskarnas stöd i det högerextremistiska pilkorspartiets händer. Deporteringarna återupptogs i november under vidriga förhållanden och sedan, i den kaotiska situationen som inträdde efter det att Budapest omringats av de ryska arméerna, dödades tusentals judar av härjande och okontrollerade pilkorsargäng.

När Ungern definitivt befriades från tyskarna var av de över 800000 judarna som levde i Ungern i mars 1944 drygt 120000 kvar. Ändå var Ungern det enda landet dit judarna återvände i stort antal efter kriget.

\section{(C) Attila Lajos}

[1] Kazarerna var ett vandrarfolk med turkiskt språk under vilkas tryck ungrarna till slut flyttar vidare. De trängde 896 in i Pannonien och grundade år 1000 under Sankt Stefans ledning det ungerska feodala kungariket. En stor del av kazarernas övre skikt övergick till judendomen någon gång under första århundradena i vår tideräkning. Därifrån kom de förmodade tidiga kontakterna. Se Száraz György, Egy elöitélet nyomában (På spaning efter en fördom), i Zsidokérdés, asszimilácio, antiszemitizmus, Budapest 1984, s. 301.

[2] Se Fejtö Ferencz, Magyarsag, zsidóság. Budapest 2000. Beskrivningen som följer nedan grundar sig också på Braham 1997, kap. 3, s. 73-107.

[3] Prepuk Anikó, s. 103.

[4] Chassidismen är en djupt religiös och starkt konservativ inriktning inom judendomen, som betonar den inre inlevelsen framför den rituella noggrannheten.

[5] Fejtö, 2000, s. 82.

[6] Främst influerad av den store judiska reformatorn, Mose Mendelsohns idéer. (Se Fejtö, Ferenc, Magyarság, zsidóság (ungersk övers. av Hongrois et juif. Histoire millénaire d'un couple singulier 1000-1957. Contribution a l'étude de l'intégration et du rejet. Paris, 1997), Budapest 2000, s. 83 (Fejtö, 2000).

[7] Då redan i dubbelmonarkien Österrike-Ungern, som bildas 1867 genom att Ungern får fullständigt inre autonomi inom riket; som jude räknades de som var av judisk religion 
(israeliter).

[8] Inklusive det kroatiska - slavoniska riket, som också styrdes från Budapest.

[9] 1867 gavs judarna samma rättigheter som de kristna och 1895 jämställdes den mosaiska religionen med den kristna.

[10] Se N. Szegvári Katalin, Numerus klausus rendelkezések az ellenforradalmi

Magyarországon, Budapest 1988, s. 26-27.

[11] Lagen XVII från 22 december, 1867 deklarerar att: "Landets israelitiska befolkning berättigas att begagna sig på samma sätt av de politiska och juridiska rättigheterna som landets övriga kristna befolkning." (Min översättning av den ungerska originaltexten citerad i Braham, Randolph L., A népirtás politikája, Budapest 1997, s. 3.)

[12]I introduktionskapitlet till Braham, Randolph L., Miller, Scott ed., The nazi's last victims. The Holocaust in Hungary, Detroit 1998, s. 28.

[13]Braham, 1997, s. 2.

[14] Magyar = ungrare (alla "a" i ordet läses som "a" i det svenska ordet "bad" och "gy" som "dj"); magyarisera: göra till ungrare. Den allmänna ungerska uppfattningen var att dessa olika folkslag bara utnyttjade vakuumet som skapades efter de enorma ungerska blodförlusterna i krigen med turkarna, flyttade in och tog gammal ungersk mark i besittning. De förökade sig mer än ungrarna inom det ungerska medeltida kungarikets gränser eftersom de - som livegna bönder - inte deltog i det i 150 år pågående kriget. Den andra delen kom efter den senare österrikiska koloniseringspolitiken, vars syfte var att försvaga den ungerska andelen av befolkningen. Nu ville de ledande ungerska skikten återskapa det medeltida ungersktalande riket, och judarna stödde fullhjärtat dessa strävanden.

[15] Se Prepuk, Aniko, A zsidóság Közép és Kelet - Europában (Judendomen i Centraloch Östeuropa), Budapest 1997, s. 102. För att illustrera hur hög denna siffra var räcker med en enda jämförelse. I Polen 1921 deklarerade nästan $90 \%$ av judarna att de hade yiddish eller hebreiska som sitt modersmål och runt $10 \%$ att de hade polska som modersmål. I Ungern efter Trianon var nästan 100 \% av judarna ungersktalande. Se Mendelsohn, Ezra, The Jews of East Central Europe between the World Wars, Bloomington, 1983, s. 30-31 och 100 (Mendelsohn).

[16] Redan 1843 skapas en Magyariseringssällskap bland de judiska studenterna i Budapest med mål att sprida den ungerska kulturen och språket bland de tysktalande judarna; se i Silber, Mickael K., The social composition of the Pest radical reform society. [17] Braham, 1997, s. 10. Denna identifiering blir så stark att de bevarar sin ungerska identitet även när de hamnar i grannländerna som formas efter första världskriget. På så sätt blir de dubbla främlingar i dessa länder och hatade både för deras judiskhet och ungerska identifiering.

[18] Se en detaljerad statistisk översikt i Braham, 1997, s. 76-77.

[19] Fejtö, 2000, s. 122. Han visste förmodligen vad han talade om ty han var ungersk jude född och uppväxt i Budapest. Se också Fejtös slutsats i kapitlet A cionizmus elutasitása (Sionismens tillbakavisande) i Fejtö, 2000, s. 121-125.

[20] se Fejtö, 2000, s. 170-179.

[21] Utan att räkna med de starka och djuprotade antiryska känslorna som fanns hos det ungerska folket i allmänhet.

[22] Att National Museets guldföremål inte stals beror på den amerikanske generalen Bandholtz som förhindrade det (med sin ridpiska, sägs det).

[23] I exakta siffror: befolkningen före kriget: 18264 533; efter: 7615 117; förlorad bef.: 10649416 av vilka

3216123 ungrare. Av territoriet på 282870 km² återstod 92963 (se Romsics, s. 143).

[24] Béla Kun och hans regering ofta tog "rationella" beslut som bortsåg från djuprotade nationella känslor i Ungern. Vid beslutet att tillkalla den rysksovjetiska armén till hjälp, t.ex. tog han och regeringens övriga medlemmar inte hänsyn till det att ungrarna betraktade ryssarna som den största nationella fienden. När de beslutade om en omedelbar förstatligande av jordegendomarna bortsåg de från böndernas vilja och känslor och litade alltför mycket på "rationella" övertalningsmetoder. Se t.ex. Braham 1997, s. 14-15.

[25] Se Braham, 1997, s.14-16.

[26] Som filosoferna Georg Lukács och Karl Mannheim, biologen Teodor Karman, 
Einsteins nära medarbetare fysikern Leo Szilard, målaren Benjamin Ferenczy, konstsociologen Arnold Hausser, fotoartisten Moholy Nagy Laszlo (som båda skulle bli två av Bauhaus grundare).

[27] Det fanns en djup klyfta mellan dessa nya och mestadels ortodoxa judiska grupper och den stora gruppen assimilerade judar som bodde i Budapest och de övriga städerna. Klyftan var så djup att de inte ens hade kontakt med varandra. Den stora klasskillnaden bidrog också till skapandet av denna klyfta. Flera av mina assimilerade informanter från medelklassen bekräftade denna segregation. De påpekade, med negativa övertoner, att dessa ortodoxa judar talade jiddisch, medan de själva talade ungerska. Det påpekades också att dessa judar var oftast mycket fattiga.

[28] Se Ozsváth, Zsuzsanna, Can Words Kill? Braham, Randoph L., Pók, Attila, red., The

Holocaust in Hungary. Fifty Years later, N.Y. 1997 s. 80 (senare: Braham \& Pók).

[29] Kovács, Maria, Liberal professions and illiberal politics, NY., 1994 s. XVIII; (Kovács 1994). En förklaring till denna maktsituation kan hittas i aristokratins - och Horthys historiska prestige och föreställda patriotism. Detta gjorde den auktoritära regimen accepterad och kapabel att motstå extremismen från båda hållen.

[30] Det nazistiska pilkorsarpartiets ledare, Szálasi Ferenc, får som mest tre år mellan 1938-1940 och den senare så illa beryktade kommunisten Mattias Rákosi får livstidsstraff för landsförräderi. Se Romsics 232 ff.

[31] Kovács 1994, s. XIX.

[32] Churchill sade följande om Ungern efter Münchenöverenskommelsen "...had attempted to extend her post-1920 frontiers in the wake of German diplomatic victories at the expense of Czechoslovakia and Romania, while at the same time trying to maintain a neutral position in the international sphere. Hungarian diplomacy sought to avoid precise commitments to the Axis about becoming an ally in the war". Churchill, Winston S., The Second World War, vol. 3, The Grand Alliance, London, s. 147.

[33] Ungern och Österrike blev de länder som hade störst andel akademiker per capita i hela Europa. Se Kovács, Mária M., Liberal professions and illiberal politics, New York 1994, s. 53-54.

[34] Jag skriver folkslag ty judarna var inte bestämda som en nationalitet utan bara som en separat religiös grupp. Lagtexten talar om "folkslag eller nationalitet" just för att kunna tillämpas även på de ungersktalande judarna. Se N. Szegvári Katalin, Numerus clausus rendelkezések az ellenforradalmi Magyarországon, Budapest 1988, s. 122.

[35] Lagen slog framför allt mot de mindre välställda judarna - som också ansågs som de potentiella vänsteranhängarna. De rika kunde skicka sina barn på utländska universitet, vilket de också gjorde (Romsics, s. 138).

[36] ibidem.

[37] Trots den antijudiska propagandan var den ungerska allmänna opinionen inte heller beredd att tolerera några öppna antijudiska övergrepp. När ett antijudiskt attentat begicks av en nationalistiskt - antisemitiskt grupp 1922 tvingade den allmänna opinionen

auktoriteterna att handla och straffa de iblandade. Se Katzburg, Nathaniel, Hungary and the Jews, Jerusalem 1981, s. 82 (Katzburg, 1981).

[38] se Braham 1997, s. 30.

[39] Romsics, s. 188.

[40] Se Braham 1997, s. 40-41. Denna nya allians förklaras också av att i denna period försökte Ungern hitta stöd även hos de västeuropeiska länderna för sina revisionistiska planer. Det sviktande västerländska stödet i denna riktning gjorde att Ungern senare vände sig helt till Italien och sen till Tyskland för att få det nödvändiga stödet, en utrikespolitisk situation som kom att ha ödesdigra konsekvenser för judepolitiken.

[41] Braham 1997, s. 41. Den nya institutionen - KEOKH - vars namn skulle kunna översättas som "Det centrala verket för kontroll av utlänningarna" blir den som också Raoul Wallenberg skulle förhandla med för erkännandet av de svenska skyddspassen. [42] Men innan han fick posten som premiärminister fick han lova Horthy och det moderata ledarskiktet att han inte skulle störa den rådande konsolideringspolitiken och inte heller försöker anta antisemitiska lagar. Braham, 1997, s. 45.

[43] Braham 1997, s. 48.

[44] Om ordkriget som fördes mot judarna i den antisemitiska litteraturen i denna period 
skriver Maria Osváth på följande sätt: "Unimportant as this war of words may appear at first, especially if compared to those actions which later stripped the Jews of identity, home, property and family, and which placed them on the train of death, analyses of the issue reveal a causal relationship between the two phenomena: the anti-Semitic literature and cultural analyses of the period both written for and read by the non-Jewish middle class, and the shift from the law of equal rights to that of anti-Jewish measures, the laws which declared the Jews second class citizen and turned them into trainloads of matter while they still were alive." Se hennes artikel i Braham \& Pók, s. 87.

[45] Det som var gemensamt i regeringsrepresentanternas inställning i judefrågan var ett tillbakavisande av den nazistiska lösningen. Detta uppmärksammas även i de engelska och amerikanska diplomaternas rapporter som publiceras i Katzburg, 1981, s. 256-262.

[46] Se om detta även Cohen, Asher, The Halutz Resistance in Hungary 1942-1944, N.Y. 1986, s. 12-13 (Cohen, 1986).

[47] Samu Stern var ordförande i Judiska samfundet i Pest, och efter den tyska ockupationen ordförande i Centrala judiska rådet som organiseras på tyskarnas order. Han citeras i Schmidt, s. 49 (min övers.).

[48] Lagen förbereddes redan före Anschluss av premiärministern Imrédy, men det var inte alls säkert att den kunde gå igenom i parlamentet. Kort tid efter lagens genomdrivande avskedades Imrédy av Horthy. Både Katzburg och Fejtö (s. 218 ff) anser att besvikelsen över genomdrivandet av judelagarna spelade en viktig roll i detta beslut. Horthy var emot dessa lagar och ville föra en från Tyskland mera oberoende politik. Han såg i Imrédy - som innan ansågs som anglofil - en partner i detta. Den radikala vändningen i premiärministern Imrédys attityd kom efter hans visit hos Hitler i september 1938 (Katzburg (1981, s. 118). Den kan också ha underbyggts av västmakternas bevisade svaghet $\mathrm{i}$

Münchenöverenskommelsen. Imrédy blev då, enlig sin egen utsago, övertygad om att Ungerns utrikespolitiska mål kan bara förverkligas i ett nära samarbete med Tyskland och genom att följa dess krav.

[49] Kovács, s. 103-104.

[50] se Katzburg, 1981, s. 98-113.

[51] Se Katzburg 1981, s. 124-125 eller Braham 1997, s. 146.

[52]Lagen var tydligt inspirerad av Nürnberglagarna. I den deklarerades att judarna förblev judar även om de konverterade och alla som hade en judisk förälder eller två judiska moreller farföräldrar skulle betraktas som judar. Se Tilkovszky, Lóránt, A zsidótörvények (Judelagarna) i Braham \& Pók, s. 127, eller Braham 1997, s. 151-152.

[53] Se hennes artikel i Braham \& Pók, s. 105.

[54] Amerikanska diplomatrapporter talar om att Horthy betraktade lagen som "brutal and inhuman" och att även premiärministern Imrédy erkände att den antogs under tysk påtryckning. Se Katzburg 1981 s. 130. Under sådana omständigheter var det inte förvånande att myndigheterna var benägna att se mellan fingrarna. Man kunde lösa förbudet antingen genom att ta en kristen partner eller jobba i en kristen kollegas namn osv. Att dessa möjligheter fanns berättades och bekräftades av flera av mina informanter också. Att låta sig korrumperas blev en moraliskt positiv sak under dessa omständigheter i Ungern.

[55] Se några dokument om denna visit publicerade i Katzburg, 1981, s. 277-281.

[56] Då hade redan den tyska armén passerat landet i sin marsch mot Jugoslavien, och Ungern var involverat i kriget mot detta land på Tysklands sida. "There is no doubt that ... the Race Protection law of 1941 ... was introduced under direct German pressure" skriver Katzburg (1981), s. 218.

[57] Ungern gav ända till krigets slut asyl till tusentals polska soldater och officerare och även många franska militärer som lyckades fly från tysk fångenskap. Fejtö 2000, s. 236, Braham, 1997, s. 85.

[58] Braham 1997, s. 769.

[59] Arbetstjänstkompaniernas förluster översteg proportionellt sett redan de enorma förlusterna som den ungerska armén hade lidit på östrfronten. En stor del av dessa förluster skedde inte på grund av krigshandlingarna men på grund av antisemitiska övergrepp. Många officerare, som ville skona sina beväpnade ungerska soldater, använde judarna som levande minröjare. Av 50000 judiska soldater i arbetstjänst återvände bara 6000 från 
östfronten.

[60]Det tyska stödet var både politiskt och ekonomiskt. Tyskland gav stora summor pengar för att understödja den antisemitiska propagandan. Se Braham 1997, s. 144.

[61] Under förevändningen av en omfattande aktion mot Titos partisaner dödade en ungersk armégrupp under ledning av generalen Feketehalmy-Czeidner Ferenc över tre tusen civila, bland vilka mellan 700 till 1000 judar, som anklagades för samarbete med partisanerna. De begångna övergreppen framkallade en våg av protester bland den ungerska allmänheten som förorsakar regeringens ingripande. Kállay gav order om arresteringen av de skyldiga men just den mest skyldige, generalen Feketehalmy-Czeidner lyckades fly till Tyskland. Tyskarna vägrade sedan lämna ut honom till de ungerska myndigheterna. Se Fejtö s. 237, exakta siffror hos Braham 1997, s. 210. På samma sida betonar Braham att de höga officerarna som gav order om massakern var mestadels av tyskt ursprung.

[62] Tyskarna krävde judarnas märkning med davidsstjärnan, inrättning av judiska ghetton och deportation till Tyskland.

[63] En lösning av "det tyska problemet" i Ungern fanns annars på många ungerska nationalisters lista. Dessa s.k. Volksdeutch tyskar hade autonoma organisationer som just då tjänade främst Tysklands intressen. De var också en riktig reservoar för Waffen SS. Se Braham s. 235.

[64] Citerad i Halász, Dorotya, The War Refugee Board and the Destruction of the European Jewry, doktorsavhandling, Texas Christian University, 2000 (Halász) s. 29. Trots den senare, uppifrån kommenderade strävan till moderation skapade dessa lagar grunden till judarnas slutgiltiga stigmatisering och uteslutning ur samhällets kropp. Även om det inte förekom någon fysisk förföljelse i Ungern berövades judarna sina grundläggande rättigheter och stämplades som de andra.

[65] Braham skriver att de judiska ledarna varnades genom Vaada redan en vecka innan invasionen av en Abwehragent av ungerskt ursprung, men, liksom Kállay, ignorerar varningen.

[66] Ungefär 10000 personer arresteras. Se Toth Sándors artikel i Vargyai Gyula, Almási János red., A német megszállás, (Den tyska ockupationen) Budapest 1994, s. 53 (Toth, 1994).

[67] En dag innan invasionen blev Horthy bjuden av Hitler till Klessheim i Tyskland. Där godkände han deporteringen av 100000 judar för att arbeta inom den tyska krigsindustrin. Han hade inte mycket emot att de - av honom föraktade galiciska judarna deporterades, men betraktade de assimilerade judarna från Budapest som ungrare och var bestämt emot deras deportering. Se Brahams analys av Horthys inställning i Braham, 1997 s. 385-389. [68] Horthy konsulterades i ministerutnämningsfrågorna, men hans apati i dessa tider gjorde att det nästan alltid blev Veesenmayers som fick sin vilja igenom. Se t.ex. Handler, Andrew, A Man of All Connections, London 1996 s. 34-35. Fejtö Ferenc: "Det var nazisterna som formulerade målen; för den ungerska administrationen återstod bara uppgiften att verkställa dem" Fejtö 2000, s. 251 (min övers.).

[69] Se t.ex. telegrammet från Veesenmayer till Ribbentrop den 28 april där han rapporterar om utrensningarna bland de ungerska landshövdingarna och om det att ytterligare utrensningar kommer att krävas. I Braham, Randolph L., The destruction of Hungarian Jewry, 3 vol., New York 1963 (Braham, The destruction of ...), nr. 122, s. 316.

[70] Edmund Veesenmayer spelade en avgörande roll i deportationernas genomförande enlig Braham, 1997 s. 396 . I hans befogenheter ingick även den politiska styrningen av hur judefrågan sköttes. Se brevet om hans utnämning och befogenheter i Braham, The destruction of..., nr. 113, s. 302. Han hade ett avgörande inflytande på formeringen av den nya ungerska regeringen också. Se telegrammet till Ribbentrop 2 maj i ibidem nr. 124, s. 318.

[71] Omedelbart efter tyskarnas inmarsch inträdde ett slags interregnumsituation i Ungern, och ingen vågade ge besked om vad som ska göras. Se den mycket välinformerade Rudolf Kaszners kommentarer om denna period i ett vittnesmål i 13 september 1945 inför en allierad domstol, återgivet i Braham, The destruction of ..., s. 910. Se om denna period även Munkácsi (s. 19) som direkt deltog i dessa händelser.

[72] Den splittrade ungerska judenheten har aldrig haft en gemensam ledning och 
spänningarna inom denna nya ledning var betydande, speciellt mellan den gamla, etablerade neologledningen och sionisterna.

[73] Munkácsi s. 16.

[74] Sammanfattningen av dessa åtgärder i Veesenmayers telegram till Ribbentrop den 31 mars. Se Braham, The destruction of..., nr. 130, s. 333.

[75] Dessa siffror anger förmodligen det totala antalet på 100000 judar som Horthy var beredd att överlåta till tyskarna för arbete i Tyskland. Se i Braham, The destruction of ..., nr. 134, s. 342.

[76] Braham 1997, s. 420-421.

[77] Stak, Tamás, Hungary's Human Losses in World War II, Uppsala 1995.

[78] Han undertecknade inga beslut som berörde judarnas situation. Braham 1997, s. 500.

Om tyskarnas ihärdiga försök att isolera honom se t.ex. telegrammet från Altenburg,

Auswärtiges Amt. till Veesenmayer 2 april 1944, publicerad i Braham, The destruction of..., nr. 117, s. 309. Enligt Samu Stern och Ernö Petö hölls Horthy okunnig om vad som skedde på landsbygden: Braham 1997 s. 479.

[79] Se de tyska dokumenten om reaktionen till dessa interventioner i Braham, The destruction of ... nr. 179, 180 s. 405-410.

[80] Det var två rapporter från det judiska rådet i Bratislava som senare kom att kallas Auschwitz-protokollen. I slutet av april 1944 rymde två slovakiska fångar från Auschwitz och lyckades komma till Slovakien och sätta sig i kontakt med det judiska rådet $\mathrm{i}$ Bratislava. Här sammanställdes en detaljerad rapport om vad som i själva verket hände i Auschwitz och om förberedelserna som gjordes för de ungerska judarnas förintelse. Även två andra rymlingar från Auschwitz, Arnost Rosen och Czeslaw Mordovitz, lyckades senare nå den slovakiska gränsen och deras rapport bekräftade det som de första två, Rudoph Vrba och Alfred Wetzler sade. Den ungerska sionistledaren Kasztner Rezsö fick denna rapport den 28 april, men han och hans kommitté - som förhandlade med nazisterna om ett upphörande av deportationerna - bestämde sig för att inte offentliggöra rapporten för att inte sätta den eventuella överenskommelsen i fara. Men den 8 juni lämnades båda rapporterna till Fülöp Freudiger, ledaren av den judisk ortodoxa församlingen i Budapest och medlem av Judiska Rådet. Han låter dessa rapporter komma till de ungerska auktoriteternas kännedom. Händelserna var beskrivna i ett tiotal böcker och Auschwitz rapporterna finns nu i fulltext även på Internet. Också den svenska legationen fick ett exemplar i juni 1944 och skickade den till Stockholm. Konsekvensen blev kungens brev till Horthy i 30 juni, 1944. Se t.ex. Braham 1997, s. 788. Även enligt uppgift i personligt samtal med Georg Klein som själv hade sett dessa rapporter.

[81] Schmidt, s. 233, not 111.

[82] Ungerska Nationalarkivet KÜM K 64100 cs. 1944-43, s. 77 och 99.

[83] Se det judiska rådets brev i Lévai, Jenö, Eichmann in Hungary, Budapest 1961, s. 114117. Om de inre påtryckningarna. Se Braham 1997, s. 831. Den f.d. premiärministern, greve Bethlen, som gömde sig i slottet och hade ett stort inflytande på Horthy, krävde bestämt deportationernas upphörande och presenterar även en detaljerad tillvägagångsplan. Se Fejtö 2000, s. 236, Cohen 1986, s. 130. Att den antityska och antinazistiska attityden var stark i Horthys omgivning bevisas också av ett brev från det Israelitiska trossamfundets ordförandeskap den 14 februari 1945. Enlig brevet var Horthys son, Horthy Miklos den yngre och regentens kabinett chef, Gyula Ambroczy, den antityska och anti - antisemitiska rörelsens mest tillgivna ledare. Brevet var utgivet av Szita Szabolcs i A Humánum Példái, Budapest 1998, s. 37 (Humánum).

[84] Enligt en rapport om judefrågans ställning i Ungern sammanställd på utrikesministeriet för den ungerska regeringen den 15 juli. Ungerska Nationalarkivet KÜM K 63100 cs. s. 117 ff.

[85] Påven den 25 och den svenske konungen den 30 juni. Cordell Hull och Roosevelts varning kommer den 26 juni (Braham 1997 s 790). Den 5 juli kom även Antony Edens kommuniké i vilken han hotade med hårde straff alla som deltar i de antijudiska förföljelserna. Sztójay påstod för Veesenmayer den 6 juli att den ungerska underrättelsetjänsten även fick tag i ett telegram sänt av de judiska representanterna i Schweiz till USA och Storbritanniens regering med listor och adresser på förövarna och i vilket de kräver Budapests bombning. Braham, The destruction of ... nr. 187 s. 425 . Edens 
kommuniké i Ungerska Nationalarkivet KÜM K 64100 cs. s. 103. Se också kapitlet om den svenska utrikespolitiken.

[86] Jungerth-Arnothy ledde i praktiken utrikesministeriet och svarade för alla utrikesfrågorna eftersom Sztójay, som hade både posten som premiärminister och utrikesminister, var mycket sjuk vid den här perioden och orkade inte med båda uppgifterna.

[87] Texten med Horthys tal i kronkonseljen finns publicerad i dokumentsamlingen i tre volymer av Karsai Elek, red., Vádirat a nácizmus ellen, (Anklagelseakt mot nazismen) Budapest 1967, vol. 3 s.3-4 (Vádirat). Texten visar också att före konseljen av de internationella protesterna Horthy nåddes ännu bara av påvens protestbrev. [88] Braham 1997, s. $840 \mathrm{ff}$.

[89] Han utfärdade ingen deklaration om detta men omöjliggjorde deportationernas fortsättning genom att förbjuda alla de ungerska instanserna att medverka. 